\title{
The role of acupoint stimulation as an adjunct therapy for lung cancer: a systematic review and meta-analysis
}

\author{
Hai-Yong Chen ${ }^{1 \dagger}$, Shi-Guang $\mathrm{Li}^{2+}$, William CS Cho ${ }^{3 *}$ and Zhang-Jin Zhang ${ }^{1 *}$
}

\begin{abstract}
Background: Lung cancer is the leading cause of death in cancer patients. Clinical studies showed that a variety of acupoint stimulations have been extensively used for lung cancer patients, including needle insertion, injection with herbal extraction, plaster application, and moxibustion. However, the role of acupoint stimulation in lung cancer treatment was not fully reviewed.

Methods: In the present study, we conducted a systematic review and meta-analysis on the role of acupoint stimulation in lung cancer treatment by electronic and manual searching in seven databases, including Ovid (Ovid MEDLINE, AMED, CAB Abstracts, EMBASE), EBSCOhost research databases (Academic Search premier, MEDLINE, CIHAHL Plus), PreQuest (British Nursing Index, ProQuest Medical Library, ProQuest Dissertations \& Theses A\&l, PsycINFO), and ISI web of knowledge (Web of Science, BIOSIS Citation Index, Biological Abstracts, Chinese Science Citation Database), CNKI, Wanfang Data, and CQVIP.

Results: Our study showed that acupoint stimulation has strong immunomodulatory effect for lung cancer patients as demonstrated by the significant increase of IL-2, T cell subtypes (CD3+ and CD4+, but not CD8+ cells), and natural killer cells. Further analysis revealed that acupoint stimulation remarkably alleviates the conventional therapy-induced bone marrow suppression (hemoglobin, platelet, and WBC reduction) in lung cancer patients, as well as decreases nausea and vomiting. The pooled studies also showed that acupoint stimulation can improve Karnofsky performance status, immediate tumor response, quality of life (EORCT-QLQ-C30), and pain control of cancer patients.
\end{abstract}

Conclusions: Acupoint stimulation is found to be effective in lung cancer treatment, further confirmatory evaluation via large scale randomized trials is warranted.

Keywords: Acupuncture, Chinese medicine, Lung cancer, Systematic review, Meta-analysis

\section{Background}

Acupuncture has been widely used for more than three thousand years in China. It is one of the key treatment modalities in traditional Chinese medicine (TCM), which is also based on the Yin-Yang, Channel and Collateral Theories. Accordingly to TCM theories, Yin-Yang

\footnotetext{
*Correspondence: williamcscho@gmail.com; Zhangzj@hku.hk

${ }^{\dagger}$ Equal contributors

${ }^{3}$ Department of Clinical Oncology, Queen Elizabeth Hospital, 30 Gascoigne Road, Kowloon, Hong Kong Special Administrative Region, China

'School of Chinese Medicine, Li Ka Shing Faculty of Medicine, The University of Hong Kong, G/F, 10 Sassoon Road, Pokfulam, Hong Kong Special Administrative Region, China

Full list of author information is available at the end of the article
}

imbalance is the basis of diseases and stimulation of certain acupoints along the collaterals can nurture the qi (or vital energy) and rebalance Yin-Yang in the body. Recently, acupuncture has been widely developed into a variety form of acupoint stimulation, including needle insertion, injection with herbal extract, plaster application, and moxibustion, etc. [1]. Previous studies have shown that acupoint stimulation can be used to treat a variety of diseases and symptoms, e.g. insomnia [2], depression [3], and pain [4]. In recent decades, TCM is regarded as a complementary therapy to cancer patients worldwide [5-7]. A number of literatures have reported that acupoint stimulation may be effective on symptom

\section{Biomed Central}


management $[8,9]$, reduction of chemotherapy-induced side effects [10-12], and quality of life improvement [13] in cancer patients.

Lung cancer is a leading cause of cancer mortality with 1.37 million deaths in 2008 worldwide. It is the most prevalent cancer in male and the fourth prevalent cancer in female. Conventional therapies for lung cancer include surgery, radiotherapy, chemotherapy, and targeted therapies (e.g. erlotinib and bevacizumab). Recently, the use of alternative and complementary therapies is increasingly widespread $[14,15]$. We have previously found that Chinese herbal medicine, as an adjunct therapy, has advantage in the reduction of side effects and improvement of symptoms in patients with non-small cell lung carcinoma [16]. Some clinical studies have also reported the use of acupoint stimulation as a treatment for lung cancer $[17,18]$. However, the role of acupoint stimulation in treating lung cancer is not thoroughly evaluated. Thus, we conducted a systematic review and meta-analysis on the efficacy of acupoint stimulation for lung cancer patients in the present study.

\section{Methods}

\section{Selection criteria}

Included studies have to meet all of the following criteria:

1. Studies claimed as random allocation or showed the baseline data without significant difference (age, gender, and severity) among the intervention and control groups.

2. Studies had to use acupoint stimulation as the adjunct intervention, or had to use acupoint stimulation as the primary studying objective or evaluating purpose.

3. Studies had at least one control group with conventional therapies, placebo, or other appropriate controls.

4. Studies investigated at least one of the outcomes of interest listed below:

i) Immunomodulation: changes in CD3, CD4, CD8 levels of T cell, natural killer (NK) cells, and IL-2 levels.

ii) Bone marrow suppression: changes in hemoglobin, platelets, and white blood cells (WBCs).

iii) Conventional therapy-induced side effect: nausea and vomiting. Judgment of vomiting grade was based on WHO toxicity reaction: grade 0: no nausea and vomiting; grade I: nausea; grade II: casual vomiting, not requiring medication; grade III: frequent vomiting, requiring medication; grade IV: serious vomiting, uncontrolled with medication. iv) Immediate tumor response: number of patients with complete response (CR) or partial response (PR) evaluated with the WHO scale.

v) Performance status: the changes of Karnofsky performance status (KPS) scores.

vi) Other quality of life assessments, e.g. EORTC-QLQ-C30.

\section{Databases}

Four major search engines were retrieved, including:

1. OVID ${ }^{\circ}$ (Ovid MEDLINE 1946 to January 2013, AMED 1985 to 2013, CAB Abstracts 1910 to January 2013, EMBASE 1996 to February 2013).

2. EBSCOhost research databases (Academic Search premier, MEDLINE, CIHAHL Plus, all to January 2013).

3. PreQuest (British Nursing Index 1994 to January 2013, ProQuest Medical Library from starts to January 2013, ProQuest Dissertations \& Theses A\&I from starts to January 2013, PsycINFO 1806 to January 2013).

4. ISI web of knowledge (Web of Science 1956 to January 2013, BIOSIS Citation Index 2006 to January 2013, Biological Abstracts ${ }^{\oplus} 1980$ to 2012, Chinese Science Citation Database 1989 to January 2013).

The Chinese electronic databases were as the follows:

1. CNKI (China Academic Journals Full-text Database 1979 to January 2013, China Doctoral Dissertations Full-text Database 1984 to January 2013, China Masters' Theses Full-text Database 1984 to January 2013, China Proceedings of Conference Full-text Database 1953 to January 2013).

2. Wanfang Data (1990 to January 2013).

3. CQVIP (1989 to January 2013).

\section{Search strategy}

Electronic databases were searched using the following strategy:

Searching terms: (acupuncture OR acupressure OR acupoint OR massage OR meridian OR moxibustion OR moxa) AND (pulmonary cancer OR pulmonary carcinoma OR pulmonary adenocarcinoma OR pulmonary squamous cell carcinomas OR pulmonary neoplasms OR pulmonary nodules OR pulmonary tumor OR lung cancer OR lung carcinoma OR lung adenocarcinoma OR lung squamous cell carcinoma OR lung neoplasms OR lung nodules OR lung tumor OR non-small-cell lung carcinoma OR nonsmall-cell-lung carcinoma OR NSCLC OR small-cell lung carcinoma OR small-cell-lung carcinoma OR SCLC). Chinese language database was retrieved with similar search strategy. "AND" and "OR" are Boolean operators. 


\section{Risk bias assessment}

Risk bias of studies was assessed using the Cochrane Risk of Bias Assessment Tool (http://handbook.cochrane.org/, part 2, chapter 8 ). All trials were reviewed by at least two reviewers (HYC and SGL) and any disagreement was resolved through the involvement of a third reviewer in consensus conferences.

\section{Data synthesis}

All analyses were performed with RevMan version 5.2 to quantify and compare the efficacy outcomes of the treatment versus the control groups. Dichotomous data were reported as relative ratio (RR) whereas continuous data were reported as standardized mean difference (SMD) \pm standard deviation (SD). The random-effect model was employed when the study of heterogeneity $\left(I^{2}\right)$ was large than $50 \%$, otherwise a fix-effect model was used when the $I^{2}$ was less than $50 \%$. To test the heterogeneity, subgroup analysis was performed according to the types of acupoint stimulation (needle insertion, acupuncture injection with herbs, acupoint plaster application, and moxibustion). The
$Z$-test was used to compare the overall effects of the treatment groups and the control groups, differences were considered to be statistically significant when $P<0.05$.

\section{Results and discussion}

993 abstracts were retrieved with 155 duplications. 154 studies in full text were further examined. A total of 31 studies satisfied the selection criteria and were analyzed in the present study (Figure 1) and their characteristics are listed in Table 1. Acupoint stimulation varies from needle insertion, pressure, plaster application, and moxibustion to herbal extraction injection on the acupoints. The most commonly used acupoints were listed in Table 2. The risk of bias in the included studies was assessed as shown in Figure 2. The risk of bias in each study was shown in (Additional file 1: Table S1).

\section{Immunomodulation}

A remarkable increase in $\mathrm{CD} 3+\mathrm{T}$ cell level was reported in patients treated with acupoint stimulation (SMD, 0.41 [95\% CI, 0.20 to 0.62 ], $P=1 \mathrm{E}-4,9$ studies, 370 patients)

Flow chart of study selection

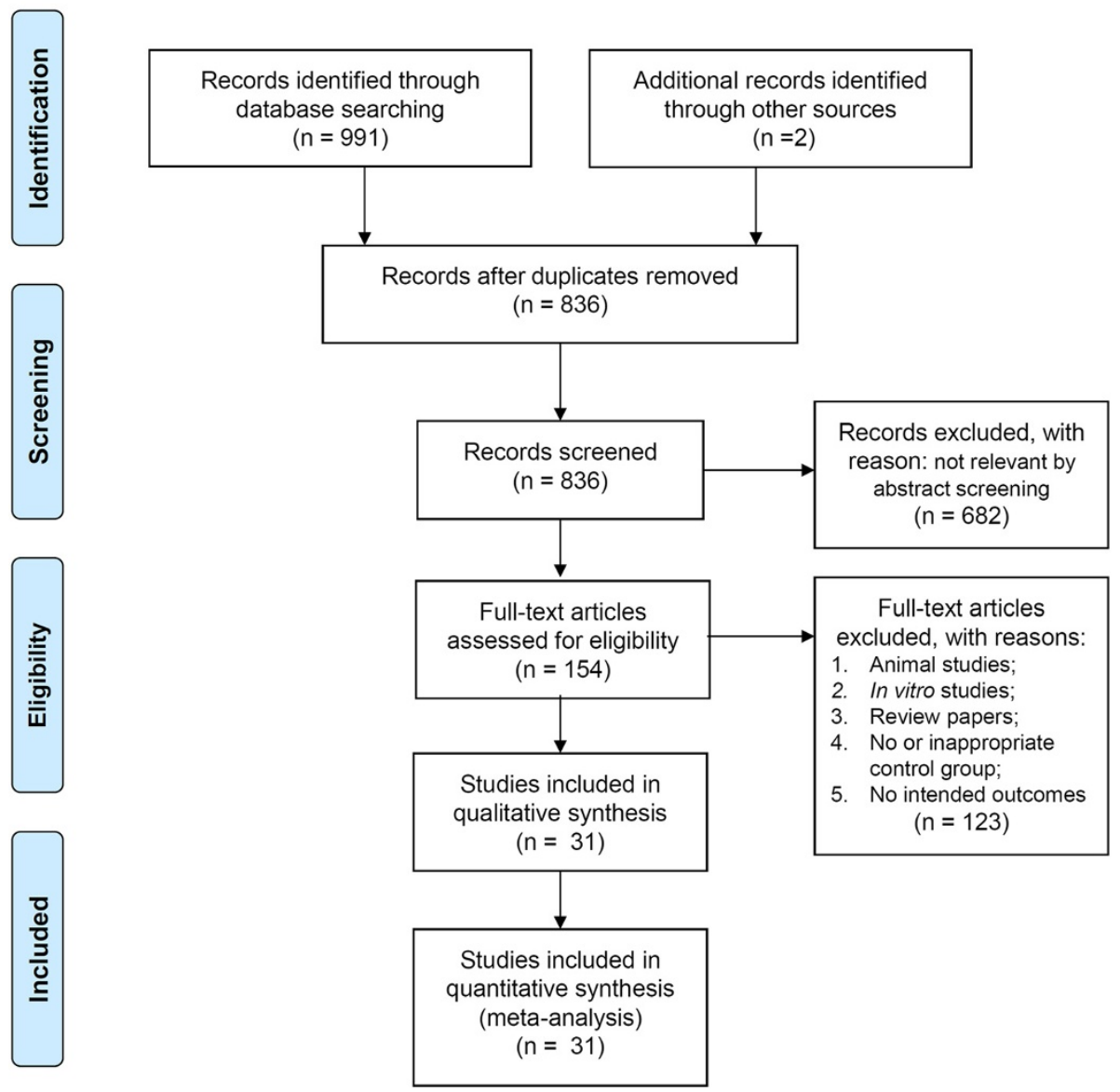

Figure 1 Flow chart of study selection. 
Table 1 Characteristics of included studies

\begin{tabular}{|c|c|c|c|c|c|c|}
\hline \multirow[t]{2}{*}{ Studies } & \multirow{2}{*}{$\begin{array}{l}\text { No. of } \\
\text { patients }\end{array}$} & \multicolumn{2}{|c|}{ Acupuncture group } & \multirow[t]{2}{*}{ Control group intervention } & \multirow[t]{2}{*}{ Assessment of outcomes } & \multirow[t]{2}{*}{ Duration } \\
\hline & & Acupoints & Intervention & & & \\
\hline Cai and Wu [19] & 80 & Fixed points: ST36 & $\begin{array}{l}\text { Acupuncture + GP and Ondansetrontdn } \\
\text { Dexamethasone }\end{array}$ & $\begin{array}{l}\text { GP and Ondansetron } \\
\text { Dexamethasone }\end{array}$ & Nausea and vomiting & 8 weeks \\
\hline Chen [20] & 32 & Fixed points: ST36 and BL23 & $\begin{array}{l}\text { Astragalus injection in acupuncture } \\
\text { points }+ \text { NP/CE and Huangqilifei } \\
\text { decoction }\end{array}$ & $\begin{array}{l}\text { NP/CE and Huangqilifei } \\
\text { decoction }\end{array}$ & $\begin{array}{l}\text { Tumor response; immunomodulation } \\
\text { (CD3+, CD4+, CD4/CD8); KPS; } \\
\text { survival rate; chemotoxicity }\end{array}$ & 8 weeks \\
\hline Chen [21] & 60 & $\begin{array}{l}\text { Fixed points: BL13, LU1, LU9, } \\
\text { ST36, PC6, etc. }\end{array}$ & $\begin{array}{l}\text { Acupuncture }+ \text { TP/GP and Chinese } \\
\text { herbs by syndrome differentiation }\end{array}$ & $\begin{array}{l}\text { TP/GP and Chinese herbs by } \\
\text { syndrome differentiation }\end{array}$ & $\begin{array}{l}\text { Tumor response; clinical symptom } \\
\text { improvement; immunomodulation }\end{array}$ & 8 weeks \\
\hline Chen [22] & 60 & Fixed points: RN4 & $\begin{array}{l}\text { Ginger moxibustion + general nursing } \\
\text { care }\end{array}$ & General nursing care & Sleep quality and WBCs & 10 days \\
\hline Chen et al. [23] & 50 & $\begin{array}{l}\text { Fixed points: LU9, PC6, ST36, } \\
\text { BL23, DU14 }\end{array}$ & Acupuncture + CAP/EP & CAP/EP & NK and leukocyte cells & 8 weeks \\
\hline Ding [24]a & 86 & $\begin{array}{l}\text { Fixed points : LU9, BL13, ST36, } \\
\text { ST40, SP3, BL20, BL43 (bilateral) }\end{array}$ & $\begin{array}{l}\text { Acupuncture + Fu zhen gan fei } \\
\text { decoction }\end{array}$ & Fu zhen gan fei Decoction & $\begin{array}{l}\text { Clinical symptom improvement; } \\
\text { WBCs; Hb; Plt; KPS }\end{array}$ & 8 weeks \\
\hline Ding [25]b & 32 & Fixed points: ST36, PC6 & $\begin{array}{l}\text { Acupuncture + cis-platinum based } \\
\text { chemotherapy and ondansetron }\end{array}$ & $\begin{array}{l}\text { Cis-platinum based } \\
\text { chemotherapy and } \\
\text { ondansetron }\end{array}$ & Nausea and vomiting & 4 weeks \\
\hline Fan \& Wei [26] & 80 & Fixed points: ST36 & $\begin{array}{l}\text { Vitamin B6 acupoint injection + NP/TP } \\
\text { chemotherapy combined with } \\
\text { ondansetron }\end{array}$ & $\begin{array}{l}\text { NP/TP chemotherapy } \\
\text { combined with ondansetron }\end{array}$ & Nausea and vomiting; KPS & Not reported \\
\hline Gu et al. [27] & 40 & $\begin{array}{l}\text { Fixed points: ST36, RN4, BL23, } \\
\text { DU4 }\end{array}$ & $\begin{array}{l}\text { Acupoint plaster application }+ \text { Chinese } \\
\text { herbs (unclear ingredient) }\end{array}$ & $\begin{array}{l}\text { Chinese herbs (unclear } \\
\text { ingredient) }\end{array}$ & $\begin{array}{l}\text { Immunomodulation (CD3+, CD4+, } \\
\text { CD4/CD8), IL-2 }\end{array}$ & 8 weeks \\
\hline He \& Lou [28] & 49 & $\begin{array}{l}\text { PC6, LI10, SP46, SP4 (bilateral); } \\
\text { RN12 (unilateral); auricular point: } \\
\text { liver, spleen, shen men, jiao gan }\end{array}$ & $\begin{array}{l}\text { Acupoint stimulation + EP with } \\
\text { ondansetron }\end{array}$ & EP with ondansetron & Nausea and vomiting; chemotoxicity & 3 days \\
\hline Huang [29] & 40 & LU9, BL13, BL17, ST36 (bilateral) & $\begin{array}{l}\text { Crude herb moxibustion (Semen } \\
\text { Brassicae, Manchurian Wildginger, } \\
\text { Ephedra sinica Stapf ) + cis-platinum } \\
\text { based chemotherapy }\end{array}$ & $\begin{array}{l}\text { Cis-platinum based } \\
\text { chemotherapy }\end{array}$ & $\begin{array}{l}\text { Chemotoxicity; living quality; body } \\
\text { weight; clinical symptoms; tumor } \\
\text { size; immunomodulation (CD3+, CD4 } \\
+, \text { CD4/CD8) }\end{array}$ & 6 weeks \\
\hline Huang et al. [30] & 80 & PC6, ST21, ST36 (bilateral) & $\begin{array}{l}\text { Acupoint plaster application + NP/GP } \\
\text { with ondansetron }\end{array}$ & NP/GP with ondansetron & $\begin{array}{l}\text { Survival; KPS; clinical symptom } \\
\text { improvement; chemotoxicity }\end{array}$ & 3 weeks \\
\hline Jiang et al. [31] & 43 & $\begin{array}{l}\text { BL23, ST36 (bilateral); DU4, RN4 } \\
\text { (unilateral) }\end{array}$ & $\begin{array}{l}\text { Acupoint plaster application decoction } \\
\text { (of herbal medicine) }+ \text { gemcitabine/ } \\
\text { pemetrexed/docetaxel }\end{array}$ & $\begin{array}{l}\text { Gemcitabine/pemetrexed/ } \\
\text { docetaxel }\end{array}$ & $\begin{array}{l}\text { Time to progression (TTP); quality of } \\
\text { life }\end{array}$ & 8 weeks \\
\hline Li [32] & 60 & BL13, BL15, BL17 (bilateral) & $\begin{array}{l}\text { Acupoint plaster application with } \\
\text { decoction (of Semen Brassicae, } \\
\text { Manchurian Wildginger, Ephedra sinica } \\
\text { Stapf) + Diprophylline }\end{array}$ & Diprophylline & Dyspnea valuated by numeric scale & 7 days \\
\hline Lin et al. [33] & 83 & BL17 (bilateral) & Acupuncture + NP/EP & NP/EP & $\begin{array}{l}\text { Chemotoxicity (reduction of WBCs, } \\
\mathrm{Hb}, \mathrm{Plt} \text { ) ; KPS }\end{array}$ & 10 days \\
\hline Lin et al. [34] & 80 & $\begin{array}{l}\text { four flowers acupoints: BL17, } \\
\text { BL19 (bilateral) }\end{array}$ & $\begin{array}{l}\text { Moxibustion + NP with Granisetron } \\
\text { hydrochloride }\end{array}$ & $\begin{array}{l}\text { NP with Granisetron } \\
\text { Hydrochloride }\end{array}$ & $\begin{array}{l}\text { Chemotoxicity (reduction of WBCs, } \\
\mathrm{Hb}, \mathrm{Plt} \text { ) }\end{array}$ & 10 days \\
\hline
\end{tabular}

Chemotoxicity (reduction of WBCs, 10 days 
Table 1 Characteristics of included studies (Continued)

\begin{tabular}{|c|c|c|c|c|c|c|}
\hline $\begin{array}{l}\text { Lin [34] } \\
\end{array}$ & 60 & ST36, BL13 (bilateral) & $\begin{array}{l}\text { Acupoint injection (Chuan ke zhi) }+ \\
\text { Aminophylline injection }\end{array}$ & Aminophylline injection & $\begin{array}{l}\text { KPS; immunomodulation (CD3+, CD4 } \\
+ \text { ); clinical symptoms improvement }\end{array}$ & 2 weeks \\
\hline Liu \& Wang [35] & 60 & RN12 & $\begin{array}{l}\text { Acupoint plaster application with herbal } \\
\text { medicine (Pinellia Tuber and Syzygium } \\
\text { aromaticum, etc.) + cis-platinum based } \\
\text { chemotherapy + Granisetron hydrochlor- } \\
\text { ide injection }\end{array}$ & $\begin{array}{l}\text { Cis-platinum based } \\
\text { chemotherapy }+ \text { Granisetron } \\
\text { Hydrochloride injection }\end{array}$ & KPS; appetite score & 3 days \\
\hline Lou [36] & 51 & bilateral: ST36, RN4, LU5 & Acupoint magnet $+\mathrm{GP}$ & GP & $\begin{array}{l}\text { Immunomodulation (CD3+, } \mathrm{CD} 4+\text {, } \\
\mathrm{CD} 4 / \mathrm{CD} 8)\end{array}$ & 2 weeks \\
\hline Ou Yang et al. [37] & 69 & RN8 & Moxibustion with salt + NP/GP & $N P / G P$ & $\begin{array}{l}\text { Clinical symptom improvement; } \\
\text { immunomodulation (CD3+, CD4+, } \\
\text { CD11+); nausea and vomiting }\end{array}$ & $4 \sim 8$ weeks \\
\hline Qiao et al. [38] & 56 & Ashi acupoints, ST36, KI1 & $\begin{array}{l}\text { Millimeter wave treatment }+ \text { Gu se fang } \\
\text { granules }\end{array}$ & Gu se fang granules & Clinical symptom improvement; KPS & 4 weeks \\
\hline Shi et al. [39] & 32 & $\begin{array}{l}\text { ST36, BL23, BL20, RN6, RN4, LU10, } \\
\text { LI10, LI4, SI3, PC4, PC6, SJ6 } \\
\text { (bilateral) }\end{array}$ & Acupuncture + general anesthesia & General anesthesia & $\begin{array}{l}\text { Immunomodulation (CD3+, CD4+, } \\
\text { CD4/CD8) }\end{array}$ & Not reported \\
\hline Tao et al. [40] & 100 & ST36, PC6 (bilateral); RN4 & $\begin{array}{l}\text { Acupoint plaster application }+ \\
\text { chemotherapy with metoclopramide or } \\
\text { ondansetron }\end{array}$ & $\begin{array}{l}\text { Chemotherapy with } \\
\text { metoclopramide or } \\
\text { ondansetron }\end{array}$ & Nausea and vomiting & 7 days \\
\hline Wang [41] & 60 & $\begin{array}{l}\text { Four flowers acupoints: BL17, } \\
\text { BL19 (bilateral) }\end{array}$ & Moxibustion + NP & NP & $\begin{array}{l}\text { TNF-a, IL-2, WBCs; nausea and vomit- } \\
\text { ing; KPS }\end{array}$ & 7 days \\
\hline $\mathrm{Xu}[42]$ & 60 & $\begin{array}{l}\text { Four flowers acupoints: BL17, } \\
\text { BL19 (bilateral) }\end{array}$ & $\begin{array}{l}\text { Fire needle therapy + GP/DP combined } \\
\text { with ondansetron }\end{array}$ & $\begin{array}{l}\text { GP/DP combined with } \\
\text { ondansetron }\end{array}$ & $\begin{array}{l}\text { Immunomodulation (CD3+, CD4+, } \\
\text { CD4/CD8); TNF-a, IL-2; KPS }\end{array}$ & 7 days \\
\hline Xu et al. [43] & 45 & ST36, DU14 & $\begin{array}{l}\text { Acupoint injection (Radix Sophorae } \\
\text { Flavescentis extraction) + anti-tumor } \\
\text { Chinese herbs }\end{array}$ & Anti-tumor Chinese herbs & $\begin{array}{l}\text { KPS; blood cells; chemotoxicity } \\
\text { (WBCs, Hb, Plt) }\end{array}$ & 4 weeks \\
\hline Xuan et al. [44] & 60 & BL13 (bilateral); DU14 & $\begin{array}{l}\text { Acupoint plaster application + traditional } \\
\text { Chinese medicine }\end{array}$ & Traditional Chinese medicine & $\begin{array}{l}\text { Immunomodulation (CD3+, CD4+, } \\
\text { CD4/CD8); KPS }\end{array}$ & 4 weeks \\
\hline Zhang [45] & 60 & $\begin{array}{l}\text { Four flowers acupoints: BL17, } \\
\text { BL19 (bilateral) }\end{array}$ & $\begin{array}{l}\text { Moxibustion + GP/DP combined with } \\
\text { ondansetron }\end{array}$ & $\begin{array}{l}\text { GP/DP combined with } \\
\text { ondansetron }\end{array}$ & $\begin{array}{l}\text { Immunomodulation (CD3+, CD4+, } \\
\text { CD4/CD8), TNF-a, IL-2, CSF; KPS }\end{array}$ & 7 days \\
\hline $\begin{array}{l}\text { Zhang \& Cheng. } \\
\text { [46] }\end{array}$ & 40 & ST36, BL13 & $\begin{array}{l}\text { Chuan ke zhi injection combined with } \\
\text { Aminophylline injection to acupoint + } \\
\text { routine treatment for symptoms }\end{array}$ & $\begin{array}{l}\text { Routine treatment for } \\
\text { symptoms }\end{array}$ & $\begin{array}{l}\text { Lung function, clinical symptoms; } \\
\text { immunomodulation (CD3+, CD4+, } \\
\text { CD4/CD8) }\end{array}$ & 2 weeks \\
\hline Zhou et al. [47] & 15 & $\begin{array}{l}\text { ST36, BL23, BL20, RN6, RN4, LU10, } \\
\text { LI10, LI4, SI3, PC4, PC6, SJ6 } \\
\text { (bilateral) }\end{array}$ & Acupuncture + general anesthesia & General anesthesia & $\begin{array}{l}\text { Immunomodulation (CD3+, CD4+, } \\
\text { CD4/CD8) }\end{array}$ & Not reported \\
\hline Zhou et al. [48] & 35 & $\begin{array}{l}\text { Acupoint selection treatment } \\
\text { based on syndrome } \\
\text { differentiation }\end{array}$ & $\begin{array}{l}\text { Abdominal acupuncture + routine } \\
\text { treatment for symptoms }\end{array}$ & $\begin{array}{l}\text { Routine treatment for } \\
\text { symptoms }\end{array}$ & KPS, EORTC-QLQ-C30 & 4 weeks \\
\hline
\end{tabular}


Table 2 Commonly used acupoints

\begin{tabular}{lll}
\hline Acupoints & Counts & Frequency (\%) \\
\hline ST36 (Zu San Li ) & 19 & 64.5 \\
PC6 (Nei Guan) & 8 & 25.8 \\
BL17 (Ge Shu) & 8 & 25.8 \\
BL13 (Fei Shu) & 7 & 22.6 \\
RN4 (Guan Yuan) & 7 & 22.6 \\
BL23 (Shen Shu) & 6 & 19.4 \\
\hline
\end{tabular}

(Figure 3A), and the heterogeneity test indicated no significant difference among those studies [20,21,27,29, $36,39,42,46,47]$. Subgroup analysis showed that acupoint needle insertion (SMD, 0.35 [95\% CI, 0.04 to 0.66], $P=0.03,4$ studies) and acupoint injection with herbs (SMD, 0.59 [95\% CI, 0.12 to 1.07], $P=0.01,2$ studies) had advantage in improving $\mathrm{CD} 3+$ while acupoint plaster application (SMD, 0.22 [95\% CI, -0.19 to 0.64], $P=0.29,2$ studies) had no significant advantage in CD3+ improvement.

We also observed an improvement in the $\mathrm{CD} 4+\mathrm{T}$ cell level (SMD, 0.61 [95\% CI, 0.42 to 0.80], $P<1 \mathrm{E}-5,10$ studies, 459 patients) (Figure 3B) [20,21,27,36,37,39,42, 44,46,47]. Subgroup analysis showed that acupoint needle insertion (SMD, 0.50 [95\% CI, 0.19 to 0.82], $P=0.002,4$ studies) and acupoint injection with herbs (SMD, 0.72 [95\% CI, 0.17 to 0.83 ], $P=0.003$, 2 studies) had advantage in improving $\mathrm{CD} 4+$ while acupoint plaster application (SMD, 0.50 [95\% CI, 0.17 to 0.83 ], $P=0.003,3$ studies) had no significant advantage in CD4+ improvement.

The CD8+ T cell level in patients treated with acupuncture has shown no significant difference compared with the control group (SMD, 0.0 [95\% CI, -0.19 to 0.19 ], $P=1.0,10$ studies, 459 patients) (Additional file 2: Figure S1A) [20,21,27,36,37,39,42,44,46,47]. Subgroup analysis showed that acupoint injection with herbs $(\mathrm{SMD}=-0.67,95 \% \mathrm{CI}=-1.15$ to $-0.20, \mathrm{p}=0.006,2$ studies) had advantage in lowing CD8+, acupoint plaster application (SMD, 0.21 [95\% CI, -0.18 to 0.61 ], $P=0.29$, 2 studies) had advantage in upregulating CD8+, and acupoint needle insertion (SMD, 0.0 [95\% CI, -0.31 to $0.31], P=0.99,4$ studies) had no significant advantage. Heterogeneity test indicated a significant difference among the acupoint needle insertion subgroup. After further removing any study among them, the acupoint needle insertion group still showed no significant alternation compared with the control groups.

As shown in Additional file 2: Figure S1B, the pooled studies indicated that acupoint stimulation can increase chemotherapy-induced NK cell reduction compared to the control group (SMD, 0.59 [95\% CI, 0.21 to 0.97], $P=0.002$, 3 studies, 114 patients) [20,23,47]. Among them, two studies used needle insertion and the left used acupoint injection with herb extraction.

Four studies used IL-2 as the outcome measurement to assess the efficacy of acupoint stimulation as an adjunct therapy for lung cancer $[27,41,42,45]$. The acupoint stimulation group showed a slightly better outcome than the control (SMD, 0.28 [95\% CI, 0.01 to 0.55 ], $P=0.04,4$ studies, 220 patients) (Additional file 2: Figure S1C).

There was no significant difference in the baseline of CD3+, CD4+, CD8+ T cells, NK cells, and IL-2 between the acupoint stimulation and control groups as shown in Table 3.

\section{Bone marrow suppression}

The pooled study showed that the prevention against hemoglobin reduction was significantly in favor of the acupoint stimulation group (SMD, 0.40 [95\% CI, 0.17 to 0.63 ], $P=7 \mathrm{E}-4,5$ studies, 296 patients) (Additional file 2: Figure S2A) $[24,42,43,45,49]$. There was no significant heterogeneity among these studies $(P=0.64)$.

The number of patients with decreased platelets was significantly reduced in the acupoint stimulation group (SMD, 0.28 [95\% CI, 0.05 to 0.51], $P=0.02,5$ studies, 296 patients) (Additional file 2: Figure S2B) $[24,42,43,45,49]$.

The inhibition of WBCs in lung cancer patients with acupoint stimulation was significant reduced (SMD, 0.93 [95\% CI, 0.44 to 1.42], $P<2 \mathrm{E}-4,8$ studies, 519 patients) $[22,24,33,34,42,43,45,49]$, but there was a prominent

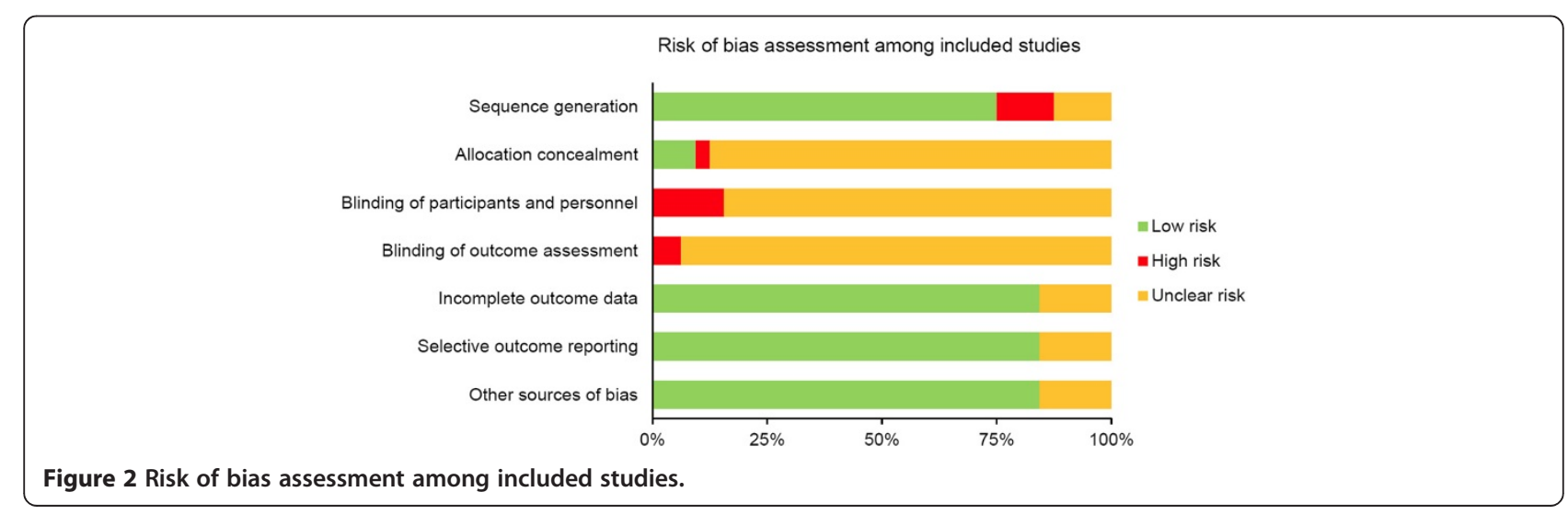


A. $\mathrm{CD} 3+\mathrm{T}$ cells

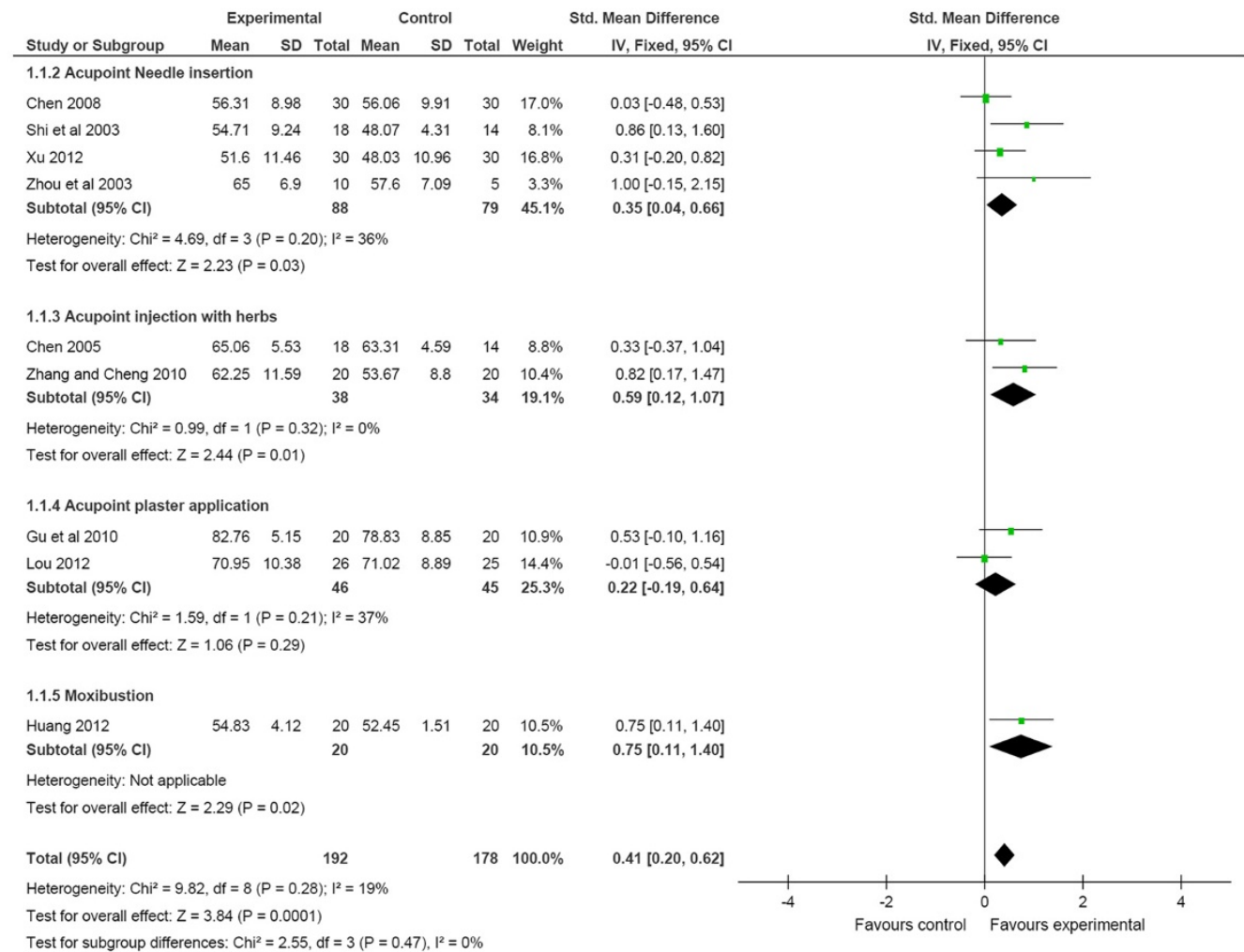

\section{B. CD4+ T cells}

Experimental Control Std. Mean Difference Std. Mean Difference

Study or Subgroup Mean SD Total Mean SD Total Weight IV Fixed, $95 \% \mathrm{Cl}$

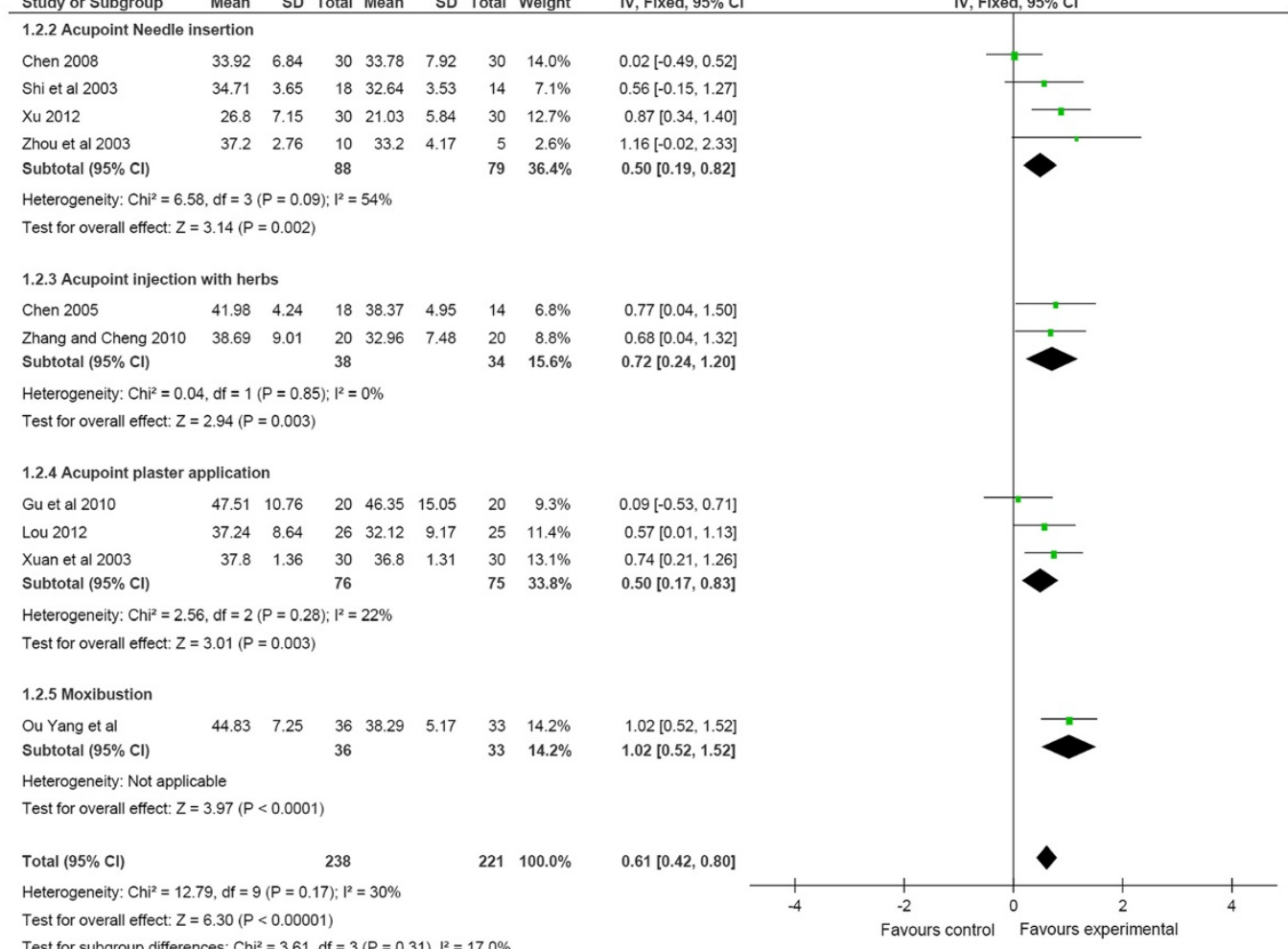

Figure 3 Immunomodulation of acupuncture in lung cancer patients. (A) CD3+ T cells; (B) CD4+ T cells. 
Table 3 Baseline of included studies

\begin{tabular}{llll}
\hline Index & Standard mean difference $\mathbf{9 5 \%} \mathbf{C l}$ & Heterogeneity & Overall effect $(\boldsymbol{P}$ value $)$ \\
\hline Immunomodulation & & & \\
CD3+ T cells & $0.07[-0.30,0.44]$ & $P^{2}=67 \%$ & $Z=0.35(P=0.72)$ \\
CD4+ T cells & $-0.04[-0.31,0.24]$ & $P^{2}=52 \%$ & $Z=0.27(P=0.79)$ \\
CD8+ T cells & $-0.01[-0.19,0.18]$ & $P^{2}=0 \%$ & $Z=0.08(P=0.94)$ \\
Natural killer cells & $-0.38[-1.39,0.62]$ & $P^{2}=79 \%$ & $Z=0.75(P=0.45)$ \\
IL-2 & $0.05[-0.21,0.32]$ & $P^{2}=0 \%$ & $Z=0.39(P=0.70)$ \\
Bone marrow suppression & & $P^{2}=0 \%$ & $Z=0.37(P=0.71)$ \\
Hemoglobin & $0.04[-0.19,0.27]$ & $P^{2}=0 \%$ & $Z=0.53(P=0.60)$ \\
$\quad$ Platelets & $0.06[-0.17,0.29]$ & & $Z=0.75(P=0.45)$ \\
$\quad$ White blood cells & $0.07[-0.11,0.24]$ & $P^{2}=0 \%$ & $Z=0.93(P=0.35)$ \\
Clinical efficacy & & & \\
$\quad$ Karnofsky performance score & $-0.08[-0.25,0.09]$ & & \\
\hline
\end{tabular}

heterogeneity among these studies $(P=1 \mathrm{E}-5)$ (Additional file 2: Figure $\mathrm{S} 2 \mathrm{C}$ ). Sensitivity test showed that removing any of the studies did not alter the patterns, however, there is still heterogeneity among the studies (data not shown).

As shown in Table 3, there was no significant difference in the baseline of hemoglobin, platelets, and WBCs between the acupoint stimulation and control groups.

\section{Nausea and vomiting}

As shown in Figure 4, the occurrence of chemotherapyinduced nausea and vomiting at Grade II-IV was remarkably reduced in the acupoint stimulation group compared to the control group (RR, 0.46 [95\% CI, 0.37-0.51], $P=1$ E-5, 8 studies, 501 patients) $[19,20,25,26,28,41,42,45]$. Subgroup analysis showed that acupoint needle insertion, acupoint injection with herbs, and moxibustion significantly attenuated the grade of nausea and vomiting $(P=0.02, P=0.005$, and $P=0.01$, respectively).

\section{Clinical efficacy}

The immediate tumor response indicated that acupoint stimulation had a significant advantage compared to the control group (RR, 1.54 [95\% CI, 1.15 to 2.07], $P=0.004,3$ studies, 148 patients) (Figure 5A) [20,38,49]. Two studies used acupoint injection with herb extraction and one used microwave treatment in the assessed studies.

The pooled KPS Scale showed a significant increase of clinical performance in the acupoint stimulation group compared to the control group (SMD, 0.76 [95\% CI, 0.42 to 1.10$], P<1 \mathrm{E}-4,9$ studies, 508 patients) as shown in Figure $5 \mathrm{~B}[25,33,38,41,42,44,45,48,49]$. However, the heterogeneity study showed a significant difference among these studies. Sensitivity test indicated a significant increase of KPS in the acupoint stimulation group with removal of anyone study in the nine studies. Subgroup analysis showed that acupoint injection with herb extraction, plaster application, and moxibustion had significant advantage in KPS without heterogeneity in studies $(P=0.0002, P=0.001$, and $P<0.0001$ respectively). Acupoint needle insertion also had no advantage in KPS, but Zhou et al.'s study in the needle insertion group showed a high heterogeneity $\left(P=0.51, I^{2}=79 \%\right)$ compared to the other two studies [48]. The baseline of KPS showed no significant difference between the acupoint stimulation group and the control group (Table 3).

EORTC-QLQ-C30 also showed a total favorable score in the acupoint stimulation group compared to the control group (SMD, 0.47 [95\% CI, 0.04 to 0.90], $P=0.03,2$ studies, 85 patients) as shown in Figure 6A [31,48]. In addition, the Visual Analog Scale had a significant improvement in the acupoint stimulation group compared to the control group (SMD, -1.13 [95\% CI, -1.58 to -0.69 ], $P<1$ E-5, 2 studies, 92 patients) [20,32] (Figure 6).

\section{Discussion}

In the present study, we systematically reviewed the role of acupoint stimulation in lung cancer management. Our results showed that acupoint stimulation has immunomodulatory effect for lung cancer patients, which was demonstrated by a significant increase of IL-2, CD3+ and CD4+ T cells, NK cells, but not CD8+ T cells. Further analysis also revealed that acupoint stimulation remarkably reduces the conventional therapy-induced bone marrow suppression, enhances hemoglobin and platelets in lung cancer patients, and decreases the chemotherapy-induced nausea and vomiting. In addition, the pooled studies also showed that acupoint stimulation has an advantage in the improvement of performance status, immediate tumor response, and quality of life (EORCT-QLQ-C30).

We found that acupoint stimulation enhances $\mathrm{T}$ cell subtype CD3+ and CD4+ cells, but not CD8+ cells. Subgroup analysis indicated that acupoint insertion and injection with herb extraction are able to elevate the total $\mathrm{T}$ cells $(\mathrm{CD} 3+)$ and $\mathrm{T}$ helper cells $(\mathrm{CD} 4+)$ in lung cancer 


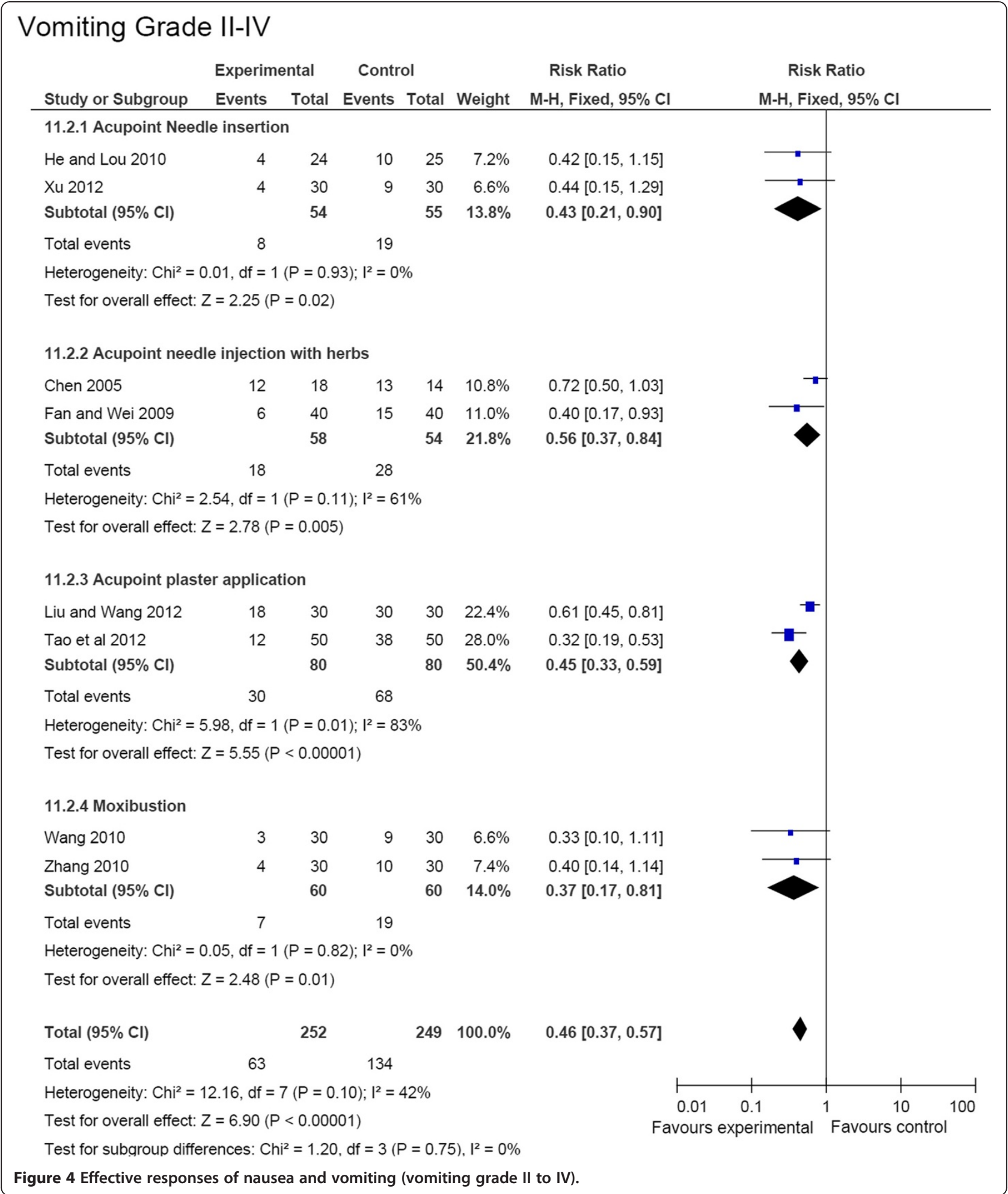

patients. Acupoint plaster application enhances CD4+ T cells, but not CD3+ T cells. CD8+ is cytotoxic T cells which are one of the most effective immune cells to kill tumor cells [50]. Interestingly, our study showed that acupoint stimulation has no significant effect on the increase of CD8+ T cells compared to the control group. Subgroup analysis showed that acupoint needle insertion has no significant effect, while acupoint injection with herbs decreases CD8+ T cells and plaster application increases CD8+ $\mathrm{T}$ cells in lung cancer patients. 


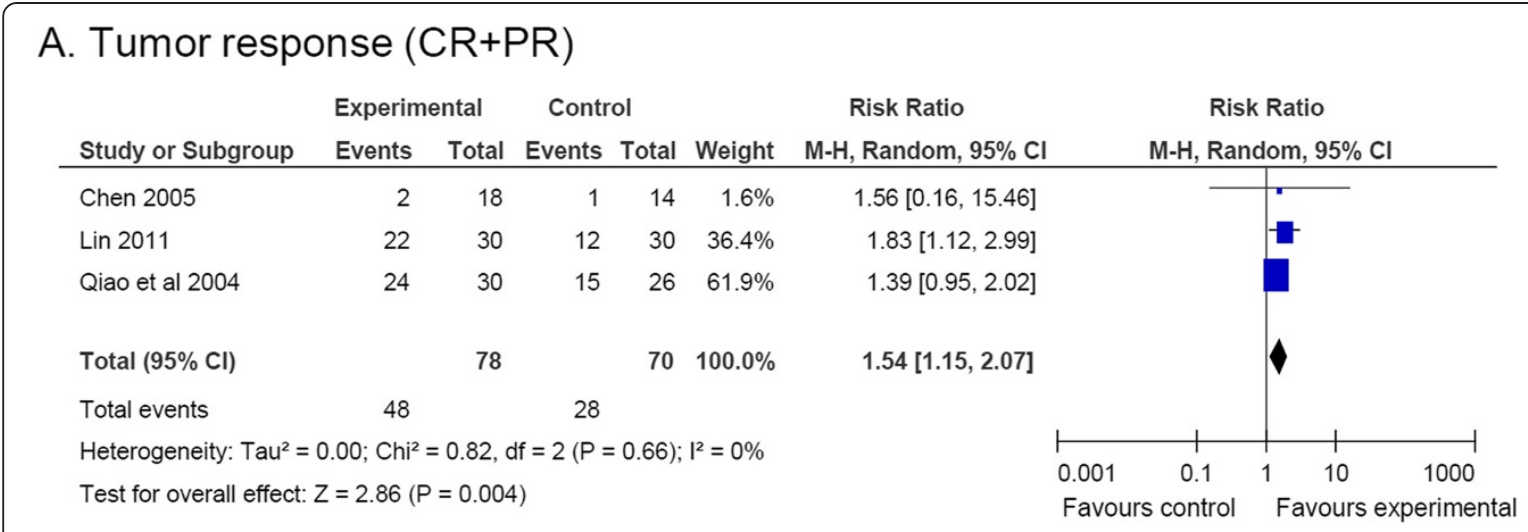

\section{B. KPS}

\begin{tabular}{|c|c|c|c|c|c|c|c|c|c|c|c|}
\hline \multirow[b]{2}{*}{ Study or Subgroup } & \multicolumn{3}{|c|}{ Experimental } & \multicolumn{3}{|c|}{ Control } & \multicolumn{2}{|r|}{ Std. Mean Difference } & \multirow{2}{*}{\multicolumn{3}{|c|}{$\begin{array}{r}\text { Std. Mean Difference } \\
\text { IV, Random, } 95 \% \mathrm{Cl}\end{array}$}} \\
\hline & Mean & SD & Total & Mean & SD & Total & Weight & IV, Random, $95 \% \mathrm{Cl}$ & & & \\
\hline \multicolumn{12}{|c|}{ 10.2.2 Acupoint Needle insertion } \\
\hline Lin et al 2010 & 57.56 & 10.19 & 41 & 45.24 & 18.18 & 42 & $12.5 \%$ & $0.83[0.38,1.27]$ & & & \\
\hline Xu 2012 & 72.33 & 7.28 & 30 & 71.33 & 6.29 & 30 & $11.8 \%$ & $0.15[-0.36,0.65]$ & & & \\
\hline Zhou et al 2011 & 68.85 & 8.42 & 17 & 71.67 & 5.26 & 18 & $9.9 \%$ & $-0.40[-1.07,0.27]$ & & & \\
\hline Subtotal $(95 \% \mathrm{Cl})$ & & & 88 & & & 90 & $34.2 \%$ & $0.23[-0.45,0.91]$ & & & \\
\hline \multicolumn{12}{|c|}{ Heterogeneity: $\mathrm{Tau}^{2}=0.28 ; \mathrm{Chi}^{2}=9.68, \mathrm{df}=2(P=0.008) ; \mathrm{I}^{2}=79 \%$} \\
\hline \multicolumn{12}{|c|}{ Test for overall effect: $Z=0.65(P=0.51)$} \\
\hline \multicolumn{12}{|c|}{ 10.2.3 Acupoint injection with herbs } \\
\hline Lin 2011 & 51.33 & 8.99 & 30 & 45 & 6.82 & 30 & $11.6 \%$ & $0.78[0.26,1.31]$ & & & \\
\hline Xu et al 2011 & 90 & 7.6 & 15 & 82.7 & 8 & 15 & $8.9 \%$ & $0.91[0.15,1.67]$ & & & \\
\hline Subtotal $(95 \% \mathrm{Cl})$ & & & 45 & & & 45 & $20.5 \%$ & $0.82[0.39,1.26]$ & & & \\
\hline \multicolumn{12}{|c|}{ Heterogeneity: $\operatorname{Tau}^{2}=0.00 ; \mathrm{Chi}^{2}=0.07, \mathrm{df}=1(P=0.79) ;\left.\right|^{2}=0 \%$} \\
\hline \multicolumn{12}{|c|}{ Test for overall effect: $Z=3.74(P=0.0002)$} \\
\hline \multicolumn{12}{|c|}{ 10.2.4 Acupoint plaster application } \\
\hline Liu and Wang 2012 & 73.33 & 4.79 & 30 & 66.67 & 4.8 & 30 & $11.1 \%$ & $1.37[0.80,1.94]$ & & & \\
\hline Xuan et al 2003 & 65 & 6.8 & 30 & 60.1 & 6.6 & 30 & $11.6 \%$ & $0.72[0.20,1.25]$ & & & \\
\hline Subtotal $(95 \% \mathrm{Cl})$ & & & 60 & & & 60 & $22.7 \%$ & $1.04[0.40,1.67]$ & & & \\
\hline \multicolumn{12}{|c|}{ Heterogeneity: $\mathrm{Tau}^{2}=0.13 ; \mathrm{Chi}^{2}=2.72, \mathrm{df}=1(\mathrm{P}=0.10) ; \mathrm{I}^{2}=63 \%$} \\
\hline \multicolumn{12}{|c|}{ Test for overall effect: $Z=3.20(P=0.001)$} \\
\hline \multicolumn{12}{|l|}{ 10.2.5 Moxibustion } \\
\hline Wang 2010 & 61 & 9.95 & 30 & 49.33 & 10.81 & 30 & $11.3 \%$ & $1.11[0.56,1.65]$ & & $\varpi$ & \\
\hline Zhang 2010 & 72.33 & 6.4 & 30 & 64.67 & 5.07 & 30 & $11.2 \%$ & $1.31[0.75,1.87]$ & & - & \\
\hline Subtotal $(95 \% \mathrm{Cl})$ & & & 60 & & & 60 & $22.5 \%$ & $1.21[0.82,1.60]$ & & & \\
\hline \multicolumn{12}{|c|}{ Heterogeneity: $\mathrm{Tau}^{2}=0.00 ; \mathrm{Chi}^{2}=0.25, \mathrm{df}=1(P=0.62) ; \mathrm{I}^{2}=0 \%$} \\
\hline \multicolumn{12}{|c|}{ Test for overall effect: $Z=6.04(P<0.00001)$} \\
\hline Total $(95 \% \mathrm{Cl})$ & & & 253 & & & 255 & $100.0 \%$ & $0.76[0.42,1.10]$ & & & \\
\hline \multicolumn{9}{|c|}{ Heterogeneity: $\mathrm{Tau}^{2}=0.19 ; \mathrm{Ch}^{2}=27.04, \mathrm{df}=8(\mathrm{P}=0.0007) ; \mathrm{I}^{2}=70 \%$} & -2 & 0 & 4 \\
\hline \multicolumn{9}{|c|}{ Test for overall effect: $Z=4.38(P<0.0001)$} & Favours control | & Favours ex & rimental \\
\hline Test for subgroup diff & erences: $\mathrm{C}$ & $\mathrm{Chi}^{2}=6$ & $37, \mathrm{df}=$ & $=3(P=$ & $=0.09), \mathrm{I}$ & $1^{2}=52$ & & & & & \\
\hline
\end{tabular}




\begin{tabular}{|c|c|c|c|c|c|c|c|c|c|}
\hline \multirow[b]{2}{*}{ Study or Subgroup } & \multicolumn{3}{|c|}{ Experimental } & \multicolumn{3}{|c|}{ Control } & \multicolumn{2}{|c|}{ Std. Mean Difference } & \multirow{2}{*}{$\begin{array}{c}\text { Std. Mean Difference } \\
\text { IV, Fixed, } 95 \% \mathrm{Cl}\end{array}$} \\
\hline & Mean & SD & Total & Mean & SD & Total & Weight & IV, Fixed, $95 \% \mathrm{Cl}$ & \\
\hline Jiang et al 2011 & 58.33 & 16.67 & 25 & 50 & 16.67 & 25 & $58.7 \%$ & $0.49[-0.07,1.06]$ & \\
\hline Zhou et al 2011 & 62.22 & 5.33 & 17 & 59.44 & 6.95 & 18 & $41.3 \%$ & $0.44[-0.23,1.11]$ & \\
\hline Total $(95 \% \mathrm{Cl})$ & & & 42 & & & 43 & $100.0 \%$ & $0.47[0.04,0.90]$ & \\
\hline \multicolumn{9}{|c|}{ Heterogeneity: $\mathrm{Chi}^{2}=0.02, \mathrm{df}=1(\mathrm{P}=0.90) ; \mathrm{I}^{2}=0 \%$} & $\begin{array}{llll}-2 & -1 & 0 & 1 \\
\text { avours control } & \text { Favours }\end{array}$ \\
\hline
\end{tabular}

Figure 6 Quality of life assessments. QLQ-C30 total score.

Although some studies have shown that acupuncture may upregulate $\mathrm{CD} 8+$ expression in patients [51,52], there may be various mechanisms for the immunomodulatory effects of acupoint stimulation lung cancer patients. $\mathrm{T}$ helper cells (CD4+) have four subtypes, including Th1, Th2, Treg, and Th-17 cells. IL-23 is a newly identified cytokine that has close association with Th17. On the other hand, IL-23 has been shown to impair antitumor $\mathrm{CD} 8+\mathrm{T}$ cells and dendritic cells transduced with IL-23 have the ability to trigger strong antitumor activity [50].

More importantly, our findings have indicated that acupoint stimulation upregulates IL-2 in lung cancer patients. It is in line with another study that acupuncture can enhance IL-2 expression by stimulation of acupoint ST36 in rats [53]. As shown in Table 2, ST36 is the most common acupoint used for lung cancer patients. Previous study has shown that IL-2 is necessary for the growth, proliferation, and differentiation of T cells [54]. A recent study has also demonstrated that IL-2 controls the balance between Th-17 and Treg cells in the tumor microenvironment [55]. It has been hypothesized that acupuncture may also upregulate NK cells in lung cancer patients. A number of studies have demonstrated that acupuncture is a strong immunomodulator of NK cells in animals and human [56-60]. Upregulation of NK cells may contribute to the antitumor effect in cancer patients [61].

Anemia, thrombocytopenia, and pancytopenia are the most common symptoms of bone marrow suppression during chemotherapy or radiotherapy. Our findings indicated that acupuncture reduces conventional therapyinduced bone marrow suppression, e.g. increase of WBCs, hemoglobin, and platelets, which is in accordance with other findings that acupuncture can improve bone marrow suppression during chemotherapy [62]. Although the mechanism remains largely unknown, previous studies have provided some possible mechanisms, for examples, acupuncture induces the erythropoietin expression [63] and bone marrow megakaryocytes [62]. Moreover, upregulation of IL-2 by acupuncture promotes the mature of T cells [54]. Subgroup analysis showed that acupoint needle insertion, injection with herb extraction, and moxibustion may play different roles in modulating WBCs, hemoglobin, and platelets.

Reduction of side effects (SEs) is the main goal for using commentary therapies during conventional cancer treatments. Our previous studies have shown that Chinese herbal medicine has the advantage of minimizing chemotherapy-induced SEs in colon cancer [7], nasopharyngeal carcinoma [6], hepatocellular carcinoma [5], and nonsmall cell lung cancer [16]. These studies showed an alleviation of nausea and vomiting during TCM treatment, which is in line with our present findings that acupoint stimulation may reduce nausea and vomiting during lung cancer treatment. As acupoint stimulation has a neuromodulatory effect on GI motility and the mechanism involving endogenous opiates, it may be effective in treating chemotherapy-induced nausea and vomiting $[64,65]$. On the other hand, pain, cough, constipation, hair and weight loss are also common SEs during lung cancer treatment. However, no pooled data was analyzed due to the lack of relevant clinical studies. Therefore, whether acupoint stimulation can reduce these SEs during lung cancer treatment needs to be further explored.

Our finding also showed the enhancement of immediate tumor response, suggesting that acupoint stimulation may improve clinical symptoms and performance status. KPS analysis showed that acupoint stimulation (acupoint injection, plaster application, and moxibustion) can enhance performance status during lung cancer treatment. EORTC-QLQ-C30 is a questionnaire developed to assess the quality of life of cancer patients. The analysis of EORTC-QLQ-C30 showed that acupoint stimulation has an advantage in the improvement of quality of life. However, the supplemented questionnaire QLQ-C13 for lung cancer was not analyzed in this meta-analysis as there was only one study reporting the results of QLQ-C13.

Although the current evidence indicates that acupoint stimulation plays a positive role in lung cancer treatment. However, the different forms of acupoint stimulations may play different role in immunomodulation, 
bone marrow suppression, reduction of SEs, and improvement of performance status as demonstrated in our studies. Nevertheless, it is no doubt that using acupoint stimulation as an adjunct therapy not only can reduce the SEs of chemotherapy and radiotherapy, but also can enhance immunomodulation, attenuate bone marrow suppression, as well as improve clinical efficacy and quality of life.

Even with these promising results, there are some limitations for the present study. The frequency and duration of treatment varied in the included studies from several days to weeks, which may lead to heterogeneity in the analyzed studies. Moreover, we did not analyze the herbs used in acupoint injection and plaster application as the main purpose of this study is to evaluate the effect of acupoint stimulation as an adjunct therapy for lung cancer. But we can't exclude the herb effects in acupoint stimulation (acupoint injection and plaster application). In addition, there were a variety of control interventions that may also increase heterogeneity of the included studies.

Besides, the efficacy of acupoint stimulation on the prolongation of survival rate for lung cancer patients remains unexplored. Risk bias study showed that a number of studies are unclear with high risks in allocation concealment, blinding of participants and personnel, as well as outcome assessments. The unclear and high risk of bias in the included studies weakens the conclusion and welldesigned randomized clinical trials are warranted to confirm the efficacy of acupoint stimulation in lung cancer. In the present study, we also conducted the sensitivity test, excluding studies with less than three of seven items marked as low risk from the risk bias assessment table. The sensitivity test (data not shown) is in line with the results from the analysis of all the included studies. Although the included literatures indicate that acupuncture is effective for symptom management, reducing SEs, and improving immune response in cancer patients, the underlining mechanism on the efficacy of acupuncture is mostly unknown and this deserves further exploration by mechanistic studies. This systematic review also arouses the need for better designed randomized trials of acupuncture for lung cancer patients to support the meaningful findings of the included studies.

\section{Conclusion}

Acupoint stimulation is found to be effective in lung cancer treatment, further confirmatory evaluation via large scale randomized trials is warranted.

\section{Additional files}

Additional file 1: Table S1. Risk of bias graph for the included studies.
Additional file 2: Figure S1. CD8+, NK cells, and IL-2 in acupuncture treatment and control group. (A) CD8+, (B) NK cells, and (C) IL-2. Figure S2: Bone marrow suppression in acupuncture treatment and control group. (A) Hemoglobin, (B) Platelet, and (C) White blood cell (WBC). Figure S3: Effective response of nausea and vomiting in treatment and control group.

\section{Competing interests}

The authors declare that they have no competing interests.

\section{Authors' contributions}

WCSC and ZJZ initiated and supervised the project. SGL and HYC retrieved the databases, extracted, analyzed data, and wrote the manuscript. SGL, HYC, WCSC, and ZJZ all involved in the conception, design, interpretation of data, as well as revision and final approval of the article. All authors read and approved the final manuscript.

\section{Author details}

'School of Chinese Medicine, Li Ka Shing Faculty of Medicine, The University of Hong Kong, G/F, 10 Sassoon Road, Pokfulam, Hong Kong Special Administrative Region, China. ${ }^{2}$ Department of Oncology \& Hematology, Shenzhen Hospital of TCM, Guangdong Province, China. ${ }^{3}$ Department of Clinical Oncology, Queen Elizabeth Hospital, 30 Gascoigne Road, Kowloon, Hong Kong Special Administrative Region, China.

Received: 23 June 2013 Accepted: 5 December 2013

Published: 17 December 2013

\section{References}

1. Cao HJ, Yang GY, Wang YY, Liu JP: Acupoint stimulation for acne: a systematic review of randomized controlled trials. Acupunct Med 2013, 25:173-194.

2. Chen HY, Shi Y, Ng CS, Chan SM, Yung KK, Zhang QL: Auricular acupuncture treatment for insomnia: a systematic review. J Altern Complement Med 2007, 13:669-676.

3. Zhang ZJ, Chen HY, Yip KC, Ng R, Wong VT: The effectiveness and safety of acupuncture therapy in depressive disorders: systematic review and meta-analysis. J Affect Disord 2010, 124:9-21.

4. Leibing E, Leonhardt U, Koster G, Goerlitz A, Rosenfeldt JA, Hilgers R, Ramadori G: Acupuncture treatment of chronic low-back pain - a randomized, blinded, placebo-controlled trial with 9-month follow-up. Pain 2002, 96:189-196.

5. Cho WC, Chen HY: Transcatheter arterial chemoembolization combined with or without Chinese herbal therapy for hepatocellular carcinoma: meta-analysis. Expert Opin Investig Drugs 2009, 18:617-635.

6. Cho WC, Chen HY: Clinical efficacy of traditional Chinese medicine as a concomitant therapy for nasopharyngeal carcinoma: a systematic review and meta-analysis. Cancer Invest 2009, 27:334-344.

7. Zhong LL, Chen HY, Cho WC, Meng XM, Tong Y: The efficacy of Chinese herbal medicine as an adjunctive therapy for colorectal cancer: a systematic review and meta-analysis. Complement Ther Med 2012, 20:240-252.

8. O'Regan D, Filshie J: Acupuncture and cancer. Auton Neurosci 2010, 157:96-100.

9. Sagar SM: Acupuncture as an evidence-based option for symptom control in cancer patients. Curr Treat Options Oncol 2008, 9:117-126.

10. Lu W: Acupuncture for side effects of chemoradiation therapy in cancer patients. Semin Oncol Nurs 2005, 21:190-195.

11. Ezzo JM, Richardson MA, Vickers A, Allen C, Dibble SL, Issell BF, Lao L, Pearl M, Ramirez G, Roscoe J, et al: Acupuncture-point stimulation for chemotherapy-induced nausea or vomiting. Cochrane Database Syst Rev 2006, 2:CD002285.

12. Schroeder S, Meyer-Hamme G, Epplee S: Acupuncture for chemotherapyinduced peripheral neuropathy (CIPN): a pilot study using neurography. Acupunct Med 2012, 30:4-7.

13. Cho JH, Chung WK, Kang W, Choi SM, Cho CK, Son CG: Manual acupuncture improved quality of life in cancer patients with radiationinduced xerostomia. J Altern Complement Med 2008, 14:523-526.

14. Molassiotis A, Fernadez-Ortega P, Pud D, Ozden G, Scott JA, Panteli V, Margulies A, Browall M, Magri M, Selvekerova S: Use of complementary 
and alternative medicine in cancer patients: a European survey. Ann Oncol 2005, 16:655-663.

15. Horneber M, Bueschel G, Dennert G, Less D, Ritter E, Zwahlen M: How many cancer patients use complementary and alternative medicine a systematic review and meta-analysis. Integr Cancer Ther 2012, 11:187-203.

16. Li SG, Chen HY, Ou-Yang CS, Wang XX, Yang ZJ, Tong Y, Cho WC: The efficacy of Chinese herbal medicine as an adjunctive therapy for advanced non-small cell lung cancer: a systematic review and meta-analysis. PLoS One 2013, 8:e57604.

17. Chai X-S, Wu W-Y, Deng H, Zhou Y-S, Zhao Y-J: Treatment of 24 cases of chest pain following lung cancer by balancing acupuncture therapy. J Acupunct Meridian Tuina Sci 2008, 6:363-365.

18. Wells M, Sarna L, Cooley ME, Brown JK, Chernecky C, Williams RD, Padilla G, Danao LL: Use of complementary and alternative medicine therapies to control symptoms in women living with lung cancer. Cancer Nurs 2007, 30:45-55.

19. Cai LH, Wu BQ: Acupuncturing Zusanli (ST36) treatment for lung cancer patients with chemotherapy-induced vomiting care. Nurs J Chin People's Liberation Army 2011, 28:43-44

20. Chen WF: Clinical observation on effect of combined acupoint-injection and chemotherapy in the treatment of advanced lung cancer, Master thesis. Tianjin University of Traditional Chinese Medicine; 2005.

21. Chen DL: The clinical research of acupuncture matches the combination of TCM and chemotherapy of IIIb-IV non-small cell lung cancer, Master thesis. Guangzhou University of Chinese Medicine; 2008.

22. Chen FR: The effect of ginger moxibustion on sleep quality in patients with advanced lung cancer. In National Traditional Chinese Medicine of Nursing Association, Integrative Nursing Academic Conference and Seminar Proceedings Series. 2009:91-92.

23. Chen LL, Xie GY, Jiang KW: Acupuncture effect on immune regulation of patients with lung cancer. Zhongguo Zhen Jiu 1997, 17:197-197.

24. Ding YW: Clinical observation of acupuncture and Chinese medicine on the quality of life improve in advanced non-small cell lung cancer patients. Gansu J of TCM 2011, 24:23-25.

25. Ding L: Clinical Observation of Acupuncture on the Prevention and Treatment of Gastrointestinal Symptoms Caused by the Chemotherapy Drug Cisplatin, Master Thesis. Beijing, China: Beijing University of Chinese Medicine; 2011.

26. Fan QL, Wei QX: The Zusanli (ST36) injection prevention and treatment for lung cancer chemotherapy gastrointestinal adverse reaction. Guangxi J Tradit Chin Med 2009, 32:25-26.

27. Gu LM, Wang GQ, Xu XC, Xu JJ: Acupoint application on the influence of immune function in patients with non-small cell lung cancer. $J$ Tradit Chin Med 2010, 26:531-531.

28. He W, Lou BD: Clinical Observation on Acupuncture and Auricular Acupressure to Lung Cancer Chemotherapy-Induced Gastrointestinal Reactions. Zhengzhou, China: Hunan Acupuncture Academic Year Compilation Information of 2010; 2010.

29. Huang YL: Efficacy of the Tianjiu Moxibustion Combined with Chemotherapy for Advanced non-Small Cell Lung Cancer, Master Thesis. Guangzhou, China: Guangzhou University of Chinese Medicine; 2012

30. Huang J, Zhou YJ, Shen HM: The clinical observation of applying acupoint with vomiting-arresting pulvis to prevent and treat gastrointestinal tract reaction caused by Cis-platinum complexes. J Kunming Med Univ 2012, 33:48-50.

31. Jiang Y, Liu LS, Li CJ, Tian JH, Shen LP, Li HG: Effect of Chinese medicine comprehensive regimen as the maintenance therapy on time to progression and quality of life of patients with advanced non-small-cell lung cancer. Chin J Integr Tradit Western Med 2011, 31:1311-1316.

32. Li X: Clinical Observation of Acupoint Sticking Therapy for Lung Cancer Patients with Dyspnea Symptoms, Master Thesis. Beijing, China: Beijing University of Chinese Medicine; 2010.

33. Lin GH, Li LX, Lin LZ, Chen CY, Li QL, Guo YQ, Zhang QF: Clinical Observation on electro-acupoints' Prevention and Treatment on Chemotherapy-Induced Side Effects in Lung Cancer Patients. In International Symposium of Acupuncture and Meridian Research Review and Prospect. Beijing: China Association of Acupuncture-Moxibustion; 2010:301-304

34. Lin GH, Li LX, Zhang QF, Lin LZ: The Effect of Direct Moxibustion on Bone Marrow Suppression Induced by Lung Cancer Chemotherapy. Guangzhou, China: Acupuncture Association of Guangdong Province Twelfth Symposium on National Stroke and Spinal Disease; 2011:30-33.
35. Liu HY, Wang JH: 30 cases of dingdi of pinellia acupoint sticking Zhongwan (RN12) prevention and treatment on lung cancer patients with chemotherapy induced vomiting. Chin J Inf on TCM 2012, 19:79-80.

36. Lou T: Impact of magnetic point on the immune function of patients with non-small cell lung cancer chemotherapy. Chin J of Tradit Med SCi Technol 2012, 6:516-517.

37. Ouyang J, Cao ML: Observation of 69 cases of strong moxibustion treatment on lung cancer immune function. Acupunct Res 1992, 17:241-243.

38. Qiao ZB, Yin T, Li Z, Hu KW, Cao Y, He XL, Zuo HM, Zhou EF, Chen XY: Millimeter wave treatment with the Gu Chong Granules on the lung cancer patients quality of life. J of Beijing Univ of TCM (Clin Med) 2004, 11:1-4.

39. Shi LL, Zhou H, Tong WP: Acupuncture regulation on the T lymphocytes immune function of lung cancer patients with surgery. Shanghai J Acupunct Moxibustion 2003, 22:27-27.

40. Tao YZ, Long J, Wen J, He ZL: Acupoint application therapy on the chemotherapy- induced gastrointestinal reactions of lung cancer patients. Mod J Integr Tradit Chin, West Med 2012, 21:2961-2962.

41. Wang T: The Effect of Direct Moxibustion Sihua Acupoints for Lung Cancer Chemotoxicity, Master Thesis. Guangzhou, China: Guangzhou University of Chinese Medicine; 2010.

42. Xu YL: Influence on IL-2 TNF-a and T Lymphocyte Subsets Level with Fire Needle on Si Hua Acupoint in Chemotherapy Patients with Lung Cancer. Guangzhou, China: Master thesis, Guangzhou University of Chinese Medicine; 2012.

43. Xu TS LIM, Zhao H, Liu YL, Wang YJ: Clinical research on the wheat-grain size cone moxibustion for improving life quality of elderly NSCLC patients. J Nanjing TCM Univ 2011, 27:418-420.

44. Xuan LH, Liu LM, Xu F, Xu YG, Ling SY: Clinical and experimental studies of WenJing acupoint application treatment for non-small cell lung cancer. Master thesis Zhejiang J Tradit Chin Med 2003, 38:223-224.

45. Zhang QF: Influence on CSF TNF and IL-2 Level with Direct Moxibustion on Si Hua Acupoint in Chemotherapy Patients with Lung Cancer. Guangzhou, China: Guangzhou University of Chinese Medicine, 2010.

46. Zhang Q, Cheng J: Clinical observations of chuankezhi injection treatment on 20 cases of advanced lung cancer with COPD. Chin Gen Pract 2010, 13:2397-2399.

47. Zhou H, Tong WP, Shi LL: Influence of acupuncture on cellular immunity of T lymphocyte in patients with lung cancer operation. Shanghai $J$ Acupunct Moxibustion 2003, 22:34-35.

48. Zhou K, Wu WY, Xie MD: Abdominal acupuncture combined with external high frequency thermotherapy in advanced lung cancer patients. Guangdong Med J 2011, 32:2124-2126.

49. Lin Q: The Clinical Study of Chuankezhi Injection to the Acupoint to Treat Kidney Yang Deficiency Type of Advanced Lung Cancer of Asthma, Master Thesis. Guangzhou, China: Guangzhou University of Traditional Chinese Medicine; 2011.

50. Bronte V: Th17 and cancer: friends or foes? Blood 2008, 112:214.

51. Kou W, Bell JD, Gareus I, Pacheco-Lopez G, Goebel MU, Spahn G, Stratmann M, Janssen OE, Schedlowski M, Dobos GJ: Repeated acupuncture treatment affects leukocyte circulation in healthy young male subjects: a randomized single-blind two-period crossover study. Brain Behav Immun 2005, 19:318-324.

52. Yamaguchi N, Takahashi T, Sakuma M, Sugita T, Uchikawa K, Sakaihara S, Kanda T, Arai M, Kawakita K: Acupuncture regulates leukocyte subpopulations in human peripheral blood. Evid Based Complement Alternat Med 2007, 4:447-453.

53. Yu Y, Kasahara T, Sato T, Asano K, Yu G, Fang J, Guo S, Sahara M, Hisamitsu T: Role of endogenous interferon-gamma on the enhancement of splenic NK cell activity by electroacupuncture stimulation in mice. J Neuroimmunol 1998, 90:176-186.

54. Cantrell DA, Smith KA: The interleukin-2 T-cell system: a new cell growth model. Science 1984, 224:1312-1316.

55. Kryczek I, Wei S, Zou L, Altuwaijir S, Szeliga W, Kolls J, Chang A, Zou W: Cutting edge: Th17 and regulatory T cell dynamics and the regulation by IL-2 in the tumor microenvironment. J Immunol 2007, 178:6730-6733.

56. Johnston MF, Ortiz Sanchez E, Vujanovic NL, Li W: Acupuncture may stimulate anticancer immunity via activation of natural killer cells. Evid Based Complement Altern Med 2011, 2011:481625. 
57. Ye F, Liu D, Wang $S, X u L$ : Effects of electro-acupuncture on T cell subpopulations, NK activity, humoral immunity and leukocyte count in patients undergoing chemotherapy. J Tradit Chin Med 2007, 27:19-21.

58. Kim CK, Choi GS, Oh SD, Han JB, Kim SK, Ahn HJ, Bae H, Min BI: Electroacupuncture up-regulates natural killer cell activity Identification of genes altering their expressions in electroacupuncture induced up-regulation of natural killer cell activity. J Neuroimmunol 2005, 168:144-153.

59. Zhang R, Lao L: Acupuncture and Moxibustion in Animal Models of Cancer. In Acupuncture and Moxibustion as an Evidence-Based Therapy for Cancer. Volume 3. Edited by Cho WC, Cho WC. Heidelberg, Germany: Springer; 2012:291-311.

60. Yu Y, Kasahara T, Sato T, Guo SY, Liu YQ, Asano K, Hisamitsu T: Enhancement of splenic interferon-gamma, interleukin-2, and NK cytotoxicity by S36 acupoint acupuncture in F344 rats. Jpn J Physiol 1997, 47:173-178.

61. Vivier E, Ugolini S, Blaise D, Chabannon C, Brossay L: Targeting natural killer cells and natural killer T cells in cancer. Nat Rev Immunol 2012, 12:239-252.

62. Zhao X, Huang X, Wang H, Lu M, Tian K: Effect of acupuncturemoxibustion on bone marrow suppression and leukocytes after chemotherapy. J Acupunct Tuina Sci 2011, 9:331-335.

63. Han XM, Wei HT, Liu SY: Involvement of erythropoietin expression in acupuncture preconditioning-induced ischemic tolerance. Adv Mater Res 2012, 554:1650-1655.

64. Takahashi T: Mechanism of acupuncture on neuromodulation in the gut-a review. Neuromodulation 2011, 14:8-12.

65. Konno R, Gyi AA: Use of Acupuncture and Moxibustion in the Control of Anticancer Therapy-Induced Nausea and Vomiting. In Acupuncture and Moxibustion as an Evidence-Based Therapy for Cancer. Edited by Cho WC, Cho WC. Heidelberg, Germany: Springer; 2012:121-152.

doi:10.1186/1472-6882-13-362

Cite this article as: Chen et al: The role of acupoint stimulation as an adjunct therapy for lung cancer: a systematic review and meta-analysis. BMC Complementary and Alternative Medicine 2013 13:362.

\section{Submit your next manuscript to BioMed Central and take full advantage of:}

- Convenient online submission

- Thorough peer review

- No space constraints or color figure charges

- Immediate publication on acceptance

- Inclusion in PubMed, CAS, Scopus and Google Scholar

- Research which is freely available for redistribution 